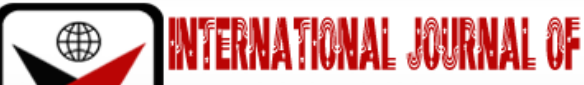

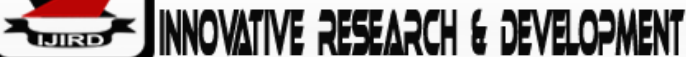

ISSN 2278 - 0211 (Online)

\section{Exploring EFL Teachers' Site-Based Professional Development: Beliefs and Practices}

Temesgen Guyassa
Lecturer, Department of English Language and Literature,
Wollega University Institute of Languages Study and Journalism
Dr. Tamiru Olana
Associate Professor, Department of English Language and Literature,
Wollega University Institute of Languages Study and Journalism
Dr. Rufael Disasa
Assistant Professor, Department of English Language and Literature,
Wollega University Institute of Languages Study and Journalism

\begin{abstract}
:
To be effective in the context of their PD practices, teachers are expected to have positive beliefs about TPD in general because what teachers practice in their professional life reflects their beliefs. Thus, this descriptive case study focused on primary school (grades 5-8) EFL teachers' beliefs and practices regarding teachers' professional development. Interviews, observations and diary writings were employed to collect data from two EFL teachers who were selected based on maximum variation sampling strategy from the total population of 19 EFL teachers who taught the target grades at the primary schools of Shambu town. Data were collected from the sampled teachers when they were in their actual work context. The collected data were analyzed based on strategy of thematic analysis. The findings of this study revealed that EFL teachers had positive beliefs about TPD in general, but their professional development practices were inconsistent with the positive beliefs they had because the teachers' professional development practices were traditional based approach of TPD. The main reason for this was that the teachers had not sustainable support from other stakeholders of education which negatively influenced them to develop negative beliefs about the practical work of ongoing teachers' professional development which is based on the contemporary approach of TPD. This means, the stakeholders of education had given less attention for the teachers, teaching profession and TPD. This influenced the participants to be inattentive about their professional responsibility, develop negative beliefs about using the current approach of TPD and work their professional development for the purpose of evaluation rather than for its real purpose that in turn influenced them to use traditional method of teaching in the classroom. Thus, to alleviate the problem, it is essential to have positive beliefs and give serious attention for the teaching profession and TPD at the side of external and internal stakeholders of education by accomplishing their professional responsibilities based on the ethics of the profession.
\end{abstract}

Keywords: EFL teachers' beliefs, stakeholders' attention, teachers' professional development, site-based TPD, stakeholders of education

\section{Introduction}

Belief is individuals' mental act of understanding something about oneself, others, and the world around us. It is used as a lens through which individuals look at something and take action in order to make it appropriate (Kocaman\&Cansiz, 2012). Teachers' belief refers the teachers' unobservable cognitive dimension of teaching.It forms part of the process of understanding how teachers shape their work which helps them to comprehend teaching methods and decisions they take in the classroom. Teachers' belief is used to provide input for the improvement of teachers' teaching practices and students' language proficiency (Gilakjani\&Sabouri, 2017; Borg, 2003, Xu, 2012).According to the scholars, teachers' belief influences the teachers' way of understanding something by portraying memories and adjusting their understanding of occurrences in light of their belief. In addition, it influences the teachers' teaching methods by guiding them adopt different teaching strategies and cope with different teaching challenges. Similarly, teachers' beliefs influence teachers' PD practices by guiding them use certain strategies of TPD. That means, teachers' beliefs have greater impact on the effectiveness of their professional development than impact that the teachers' knowledge has on the organizing program like planning, deciding, and acting in their professional development activities. So, since teachers' belief is the root of teachers' way of thinking and impacts the teachers' action in the context of their professional development practices because it impact show teachers think and what the teachers say or do in their profession, it is expected to be shaped in light of contemporary approach of TPD which is site-based teachers' professional development. Having positive 
belief towards teachers' professional development helps foreign language teachers effective in their professional development practices because it helps the munderst and contemporary approach of TPD and helps them act accordingly in the context of their professional development practices. Stockholders of education have critical role in creating opportunity of site-based TPD which positively impacts teachers to develop positive beliefs regarding TPD in general (Richards \& Farrell, 2005).As far as this reading is concerned, primary school EFL teachers' beliefs and source of the beliefs about site-based TPD practices are not clearly known in Ethiopian context. So, this study was designed to explore whether the teachers have positive belief about TPD, practice their professional development based on site-based teachers' professional development and sources of their beliefs about TPD.

\section{Literature Review}

Literature confirms that teachers' beliefs play key role in the effectiveness of teachers' professional development. It is teachers' belief that guides teachers in which they accomplish their professional responsibilities (Gilakjani\&Sabouri, 2017; Borg, 2003). Concerning their teaching profession and professional development practices, there are different sources of teachers' beliefs. According to Abdi \&Asadi (2015), teachers' experience - the way the teachers learned and the way the teachers teach, the teachers' personality - the way the teachers may prefer a particular method of acting in teaching-learning process, different theories of their profession and culture of the society around the teachers are sources of their beliefs about their teaching profession as well as their professional development practices. So, it is essentialto understand sources of teachers' beliefs andexplore the beliefs in relation to teachers' professional development in order to shape the min light of the contemporary approach of teachers' professional development practices by creating conducive condition for the teachers (Richards \& Farrell, 2005; Villegas-Riemers, 2003).

It is the responsibility of stakeholders of education that deal with beliefs of teachers and shape the existing beliefs of the teachers in light of the current model of teachers' professional development. They are expected to do these by providing job-embedded teachers' professional development practices, different trainings on the effective work of teachers' professional development, making the teachers' physical work condition attractive and providing different resources and materials(Al Asmari, 2016; Hayes, 2014; Reimers-Villegas, 2003).To do this, the stakeholders of education are expected to have positive belief towards teaching profession and teachers' professional development because it is their belief that regulates their attention towards the teaching profession and teachers' professional development (Gilakjani\&Sabouri, 2017).

One of the aims of foreign language teachers' professional development is to change beliefs and feelings of teachers to the positive one in relation to TPD (Abad, 2012).The reason is that what teachers act or react is directly influenced by their beliefs (Gilakjani\&Sabouri, 2017). So, it is critical to work on providing encouraging working condition which develops positive belief in teachers about teachers' professional development at the side of school.In doing so, the school develops positive beliefs in its teachers and helps the teachers to be effective in their professional development; it also directs everything of teachers in their professional life (Xu, 2012). So, in teachers' professional development, the attempt to develop teachers behaviorally and intellectually towards their profession without any focus on their beliefs and emotional development can be fruitless. This implies that EFL teachers' positive belief towards their professional development has positive impact on effective improvement of their teaching practices and the whole education quality (Kuzborska, 2011). This also implies that one who explores the existing beliefs in relation to teachers' professional development practices and shapes the existing beliefs in line with the contemporary approach of teachers' professional development is effective in improving teachers' teaching practices and students' language proficiency (Jensen, 2015).

Thus, having positive beliefs about teachers' professional development positively impacts EFL teachers' professional development practices because it leads the teachers to be in line with the current theory of education in their instructional process. In addition, having understanding about sources of teachers' beliefs about TPD helps any stakeholder of education examines the existing beliefs and shapes them in line with site-based model of teachers' professional development practices.

EFL teachers' professional development practice is what teachers frequently do in order to continuously improve their teaching practices. Teachers who effectively improve their teaching practices dominantly use site-based teachers' professional development practices rather than depending on knowledge of external experts which is irrelevant with teachers' needs. It also enables teachers and other stakeholders of education collaboratively work on every professional endeavor which in turn enables teachers share experience, reflect on their previous experience and use the improved teaching practices in the context of their career rather than separately making effort for improving one's teaching practices (Borg, 2015; Croft et al, 2010; Richards \& Farrell, 2005; Oxford Dictionary, 1999).

According to Richards \& Farrell (2005) and Mora, Trejo \& Roux (2013), site-based teachers' professional development practices become effective when they are supported by standardized and self-directed teachers' professional development practices. That means, teachers' professional development practices become effective when teachers participate in peer teaching, peer observation, critical friendship, action research, critical incidents, team teaching, case studies, journal writing, teacher support group, workshops, conferences, seminars, self-monitoring and teaching portfolios based on their actual work context (Richards \& Farrell, 2005; Davidson et al., 2012; Richards \& Lockhart, 1996). So, in the contemporary approach of TPD, all models are used for the purpose of supplementing site-based model of TPD which is dominant in the current approach of TPD (Korkmazgil, 2015). The reason is that site-based teachers' professional development practices are corner-stone for the teachers' professional development which profoundly and positively impact EFL teachers' teaching practices as well as students' language proficiency (Mora, Trejo \& Roux, 2013). 


\section{Objectives}

This study aimed at addressing the following objectives.

- To explore primary school EFL teachers' beliefs about teachers' professional development

- To investigate sources of the teachers' beliefs regarding teachers' professional development

- To describe impact of the teachers' beliefs on their professional development practices

\section{Materials and Methods}

\subsection{Design}

This study intended to explore EFL teachers' beliefs and sources of their beliefs in relation to site-based teachers' professional development practices and the impact of their beliefs on the teachers' professional development practices. The research was, thus, conducted based on descriptive case study as it suits the nature of the study and enables the researcher to describe the phenomena in their natural setting, code and analyze the data based on strategy of thematic analysis.

\subsection{Participants}

This study involved two EFL teachers from one primary school of the country. The teachers were selected from Shambu Primary School based on maximum variation sampling strategy. The researcher used this sampling strategy to increase diversity between the participants which helped him to collect data from participants who were in different level and context because although both of them had BA degree in English teaching, they were different in their teaching experience. That means, while one of the teachers had twelve years of teaching experience, the other one had twenty years of teaching experience at primary schools.

\subsection{Instruments of Data Collection}

In this study, interview, observations and diary writing were used for data collection. The participants were interviewed and observed in their actual working context. They were also asked to write their diary writing in relation to their daily professional activities that they did in order to improve their teaching practices during their career. So, the researcher asked the participants to write their diary before doing anything in relation to data collection because he wanted to gather data about teachers' beliefs, knowledge and practices of professional development through the instrument in an unobtrusive way. And then, the researcher employed observations to collect data in relation to the teachers' professional development practices which reflect the teachers' beliefs. Next to the observations, the study used interviews to gather data regarding beliefs and practices that the sampled EFL teachers had and engaged in respectively during their professional development.

\subsection{Procedures}

The data were collected when the teachers were in their actual working context. Since the sample size was small, the collected data were analyzed using thematic analysis. That means, the researcher started data analysis when he started data collection. Accordingly, he prepared and organized data in the way they could be read and understood. At the end of data collection, the researcher coded the data based on the basic research questions. And then, he aggregated similar codes to create broader theme. Based on this, he interpreted the data and gave conclusion.

\section{Results}

\subsection{EFL Teachers' Beliefs about TPD}

The participants had positive beliefs regarding teachers' professional development in general and its importance that it has in teaching-learning process. According to them, teachers who continuously make effort to improve their teaching practices through their professional development are effective in their teaching activities. As they specified their beliefs, the role of stakeholders of education is not simple in the effectiveness of TPD. According to them, if every stakeholder of education stands along the school and teachers concerning teachers' professional development by making the necessary support, the work of teachers' professional development becomes effective in the school. In relation to this, Teacher 1, for instance, uttered:

I believe teachers' professional development is a program which has great contribution in teaching-learning process. If teachers work their professional development from bottom of their heart, they get good result in their teaching practices. Stakeholders like teachers, school leaders, students, and the wide community have their own role for the effectiveness of teachers' professional development. If these stakeholders work on teachers' professional development together based on the actual working context of teachers, they yield good result from the program (Interview of T1).

As we can understand from the above extract, the teacher believes that the role of teachers' professional development is great in improving teachers' teaching practices. The participant also believes that site-based collaborative work of stakeholders of education on TPD has crucial role for effectiveness of the program.

In general, as one can understand from the above description, the participants of the study had positive beliefs regarding the importance and contemporary approach of teachers' professional development. The participants believe that if they work their professional development collaboratively with other stakeholders, their professional development becomes effective in achieving the goal of the program which is improving students' language proficiency. In addition, the teachers believe that to be effective in their professional development, they should be based on their working context 
rather than depending on external experts who do not consider the needs of the teachers. So, according to them, teachers' professional development is effective when the teachers start from within rather than depending on external experts.

Data from the interviews also show that the participants had positive understanding about teachers' professional development and its importance in general. According to them, teachers' professional development is a program in which teachers continuously improve their teaching practices which enable them address students' needs throughout their professional life. According to the participants, to regularly improve one's teaching practices, teachers' professional development should be in such a way that teachers update and upgrade their profession throughout their professional life. The participants expressed teachers' professional development that it is what teachers continuously do when they are in the actual teaching context to continuously improve their teaching practices and students' learning outcome by up-dating their profession based on experiences they get from the actual context of their career and up-grading their education level in different education programs. According to them, in these ways of professional development -experiences they get from their colleagues, students, and knowledge they get from the existing theories and curriculum, teachers improve many things in their teaching practices. Teacher 2, for instance, explained the idea in the following:

As it is known, teachers' professional development is a way in which teachers develop their teaching practices. This means, TPD is a program in which teachers continuously improve their teaching practices without being careless about it. Teachers are benefited if they constantly work their professional development. They are expected to have good relationship with their students and teach them based on their needs. Teachers get these skills and knowledge when they continuously work their professional development. But, we teachers are different in our professional development. That means, we are not equal in our effort to improve our teaching practices based on our working context. This is not good. Every teacher is expected to improve him or herself professionally and his or her students' learning outcome accordingly. Teachers should have deep knowledge about the subject they teach and methods of teaching the subject they teach. Since the knowledge comes from working one's school based teachers' professional development, every teacher should seriously work his or her professional development. Teachers also improve their teaching practices by improving their education level. Today, there are opportunities in which teachers improve their education level from diploma to degree, degree to MA, and MA to PhD. When teachers improve their education level, they can be successful in all directions of their teaching practices. That means, when teachers improve their education level, they can easily improve themselves professionally, their, and students school in everything (Interview of T2).

From the above extract, we can understand that the positive beliefs of the teachers about teachers' professional development helped them have knowledge about TPD in light of the contemporary approach of teachers' professional development.

However, data from the sampled interviews, observations and diary writings show that the teachers mainly used traditional method of teachers' professional development. In his interview and diary writings, Teacher 2, for instance, explained the idea that he mostly used reading related materials for the purpose of his professional development. During outside observations, the researcher confirmed that the teachers mostly used this strategy for their professional development. This means, except using few informal dialogues with their colleagues, the teachers mostly used individual reading of some related materials for their professional development. This shows that the teachers did not act for their PD based on the positive beliefs they had about TPD and use contemporary approach of TPD which is based on site-based model of TPD. This also indicates that the teachers developed new beliefs which were negative concerning the practical work of teachers' professional development.

\subsection{Sources of EFL Teachers' Beliefs about TPD}

As described in the above section, the participants had positive beliefs and knowledge about the concept, importance, and strategies of teachers' professional development in general. However, the school leaders, District Education Office and the wide community gave no attention for the teachers, teaching profession and teachers' professional development. Teacher 2, for instance, expressed the idea by saying since school leaders were assigned based on their political attitude rather than their academic performance, they gave focus for political issues rather than academic issues. He told the researcher that the teachers and other stakeholders became discouraged by the condition regarding TPD and standing beside the teachers in relation to the teachers' professional development respectively. The researcher confirmed the inattentiveness of the stakeholders about teachers and teachers' professional development during outside observation. During the observations, the researcher proved that the stakeholders did not make any material, financial, psychological and professional support for the teachers as well as school. They simply gave teachers order to work their professional development rather than collaboratively facilitating everything for TPD by standing beside the teachers and school. For this reason, the teachers developed negative beliefs and understanding about the practical work of teachers' professional development. As a result, they used traditional approach of TPD for the purpose of evaluation rather than the true purpose of TPD. This implies that the main source of the sampled teachers' negative beliefs about the practical work of teachers' professional development was being inattentive about the teachers and teachers' professional development at the side of the stakeholders of education.

\subsection{Impact of the Participants' Beliefs on Their Professional Development Practices}

As we have seen in the above sections, the sampled teachers had positive beliefs about teachers' professional development in general. Having these beliefs helped them to have positive understanding about TPD in light of the current model of the program. However, while they worked their professional development being in the context of their career, the researcher observed that there was no stakeholder who stood beside them and facilitated everything for the effectiveness of the work. As a result, the teachers developed new belief which was negative regarding the practical work 
of teachers' professional development. This negatively impacted the sampled teachers to use self-directed rather than sitebased model of TPD. During interview, the participants uttered that the main reason for the newly emerged teachers' beliefs regarding the practical work of TPD was lack of attention for the profession as well as teachers at the side of other stakeholders of education. According to them, this negatively impacted the teachers to use self-directed rather than sitebased model of TPD. Teacher 2, for instance, explained the idea in the following:

In our school, there is program of TPD but its owner who responsibly leads the program is not known. For this reason, many of us has been negatively influenced to separately work our professional development for the purpose of evaluation rather than for the real purpose of teachers' professional development because lack of attention for the program and teaching profession has negatively influenced us to think TPD is for the purpose of evaluation rather than for its real purpose (Interview of T2).

From the above quotation, we can understand that the sampled teachers' beliefs about teachers' professional development was negatively influenced by less attention other stakeholders of education have for teachers' professional development as well as the teaching profession. As a result, as data from interviews, observations and diary writings show, the teachers' positive beliefs and understanding that they had about teachers' professional development did not fitwith their PD practices because the participants practiced their professional development based on traditional approach of teachers' professional development rather than site-based model of TPD. This shows that the teachers negatively influenced and developed negative beliefs about the practical work of contemporary approach of TPD.

Although the sampled EFL teachers worked their professional development as one of their professional duties, there was no collaborative teachers' professional development in which teachers regularly meet and share goals and expertise, to improve their teaching practices and the academic performance of students. The main reason for this was that there was no formally organized peer-coaching, peer-observation, peer - teaching, teacher support groups, and action research in the school. For these reason, the teachers mostly made individual effort to improve their teaching practices that is self-directed rather than school-based model of TPD. Teacher 1, for instance, reflected the traditional method of TPD he used to improve his teaching practices through his interviews and diary writings. According to him, he took different trainings once a year on teaching English language and tried to apply the lessons he got from the trainings in his classroom teachings. In addition, he read and referred different related materials and taught his students accordingly. He also listen radio programs which are broadcasted in English language to develop his language skills. Moreover, when he was with his colleagues, he tried to speak only in English language to develop his language skills. Healso sometimes informally asked his colleagues on points he was not clear. Based on these, he tried to reflect on his previous professional knowledge and adjusted his teaching practices accordingly. However, the teacher did not write and speak about any school-based model of teachers' professional development practices during his diary writings and interviews respectively because they did not use it for the purpose of their professional development in the school.

The participants also did not accomplish their professional responsibility by creating encouraging learning condition in the classrooms as much as possible. Although they used their own notebook along student textbook and tried to give students additional note, they did not use any teaching aid to make the lessons practical. In addition, they did not accomplish their professional responsibility by creating attractive physical work condition as much as possible instead they were negligent about it. The researcher observed during classroom observation that along the disarrangement of the students' seat, the walls, floors, roofs, windows, doors, and blackboards of the classes were deteriorated. Even, the whole physical conditions of the school were not attractive. For this reason, it was unpleasant to teach students and learn being in the classrooms as well as the whole context of the school. This also shows that the professional development practices of the sampled teachers were not site-based TPD model oriented which enables teachers work on the attractiveness of their working condition because they have already developed negative cognition about the model.

As the researcher understood from the sampled teachers' diary writings and classroom observations, they tried to understand the learning condition of their students, but they were not observed when they gave practical and critical professional solutions for the problems. To solve the identified problems of the students, the teachers did not go beyond giving students every responsibility for the problems. The participants were not observed when they made formal collaboration with their colleagues to share experiences for one another based on job-embedded teachers' professional development and solve any problem they understood in relation to their professional activities. That means, instead of focusing on bottom-up approach of teachers' professional development which enables teachers improve their teaching practices and solve any problem of schooling, the teachers always tried to work their professional development superficially which cannot effectively solve any problem of profession.

In connection to the above descriptions, outside observations ascertained that most of the time, all of the sampled teachers individually worked their PD. Except few informal professional dialogues which were happened among some teachers, every teacher made individual effort for his or her professional development because there was no time when the teachers formally collaborated for their professional development. On top of this, the teachers did not make individual effort to develop their profession based on the current approach of teachers' professional development as much as possible.

Even though the teachers worked for their professional development, they did not do that based on their needs. Instead of collaboratively making needs assessment with the school leaders to identify topics on which they worked their professional development, the teachers were observed during outside observation when they simply expected and took topics for their professional development from the school leaders. That means, instead of actively and collaboratively participating in their professional development based on their needs, the teachers expected everything for their professional development from outside which is top-down approach of teachers' professional development. As a result, their professional development practices became transmission model oriented. That means, the teachers did not start 
from within and work their professional development accordingly. They simply expected everything - all size-fits-all approach - from the school leaders and tried to work their professional development separately.

However, Teachers 1 told the researcher that the school leaders created conducive condition for teachers' professional development in the school by selecting topics for their professional development. The participant expressed that based on this, the teachers came together to collaboratively work their professional development and shared their professional experiences for one another. Accordingly, he uttered, the teachers reflected on the new experience they got from their colleagues based on their previous experiences and improved their teaching practices accordingly and applied it in their teaching practices. The teacher told the researcher that by selecting topics of professional development, the school leaders created encouraging environment for bottom-up approach of teachers' professional development in the school because he wrongly understood the school leaders' independently selecting topics for teachers' professional development as one way of creating conducive environment for teachers' professional development because he did not have positive belief and enough knowledge about the practical work and contemporary approach of teachers' professional development.

As one can understand from the above accounts, the teachers used traditional approach of TPD as the main way of their professional development. They were also observed that they separately made effort for their PD rather than making collaboration for their professional development because there was no suitable condition to do that in the school. Even, they did not participate in needs assessment and topic selection for TPD. For this reason, passively receiving topics for their professional development from the school leaders, the participants focused self-directed model rather than sitebased model of teachers' professional development in the school. Moreover, the teachers wrote on their diary writing that they just used reading related materials as the main way of their PD. In consequence, as data from classroom observations show, their teaching approach was based on traditional approach of teaching that worsened students' language proficiency. This shows that the newly emerged negative beliefs of the teachers concerning the practical work of TPD negatively impacted the teachers' professional development and students' learning process.

\section{Discussion}

The sampled ELT teachers had positive beliefs about teachers' professional development in general.This helped them positively understand about concept, importance and strategies of teachers' professional development. The participants expressed their beliefs that teachers' professional development is a process of tracking and documenting the skills, knowledge, and experience that teachers gain formally and informally in which they continuously record, review, and reflect what they learn and update their profession in line with the contemporary approach of teaching-learning process to enhance students' language proficiency. In light of the teachers' beliefs, different scholars argue that teachers' professional development is a planned, continuous and lifelong process in which a teacher tries to develop his or her personal and professional qualities. According to the scholars, the process helps the teachers improve their knowledge, skills, and teaching practices which lead them to empowerment and improvement of their agency and development of their organization and pupils (Bolitho \&Padwad, 2013; Diaz-Maggioli, 2004; Alfaki, 2014).Thus, having positive belief about TPD helps teachers to have positive understanding about TPD in general and contemporary approach of TPD.

The participants of the study also believe that it is through teachers' professional development that teachers daily, weekly, monthly, annually, and continuously improve their teaching practices in line with the contemporary approach of teaching and learning. Based on this, they teach to satisfy their professional and pupils' needs of $21^{\text {st }}$ century which has profound contribution in ensuring quality education and producing outstanding generation. In relation to the teachers' beliefs, different scholars express that ongoing teachers' professional development is used for individual satisfaction, financial gain, and has a significant positive impact on teachers' beliefs and practices, students' learning, and implementation of educational reforms(Asmari, 2006; Gulamhusse in, 2013; Solak,2016).So, it is TPD that helps teachers to be proud in their profession because it enables them to have different professional benefits in the context of their professional activities.

As the teachers reflected their beliefs about strategies of teachers' professional development, teachers become effective in their professional development when they work their professional development based on site-based model of teachers' professional development. Supporting the teachers' idea, Kumaravadivelu (2006), Richards \& Farrell (2005) and Richards \& Lockhart (1996) inform us that today an important direction of TPD is a movement away from outsider approach which is based on expert knowledge as well as theories and general principles that teachers apply in their situations to the insider one which is locally based approach that encourages teachers to explore their contexts and construct their own knowledge and understandings. Hence, site-based model of teachers' professional development is the corner stone of TPD because standardized and self-directed models of TPD are used just to supplement it.

The teachers' positive belief regarding teachers' professional development positively influenced their understanding about teachers' professional development in general because it helped them make sense of things by guiding them in the way new information is understood and depicting memories and adjusting their understanding of world around them(Gilakjani\&Sabouri, 2017).However, the teachers believe that the effectiveness of teachers' professional development is based on stakeholders' participation in the work because without participation of stakeholders of education, any work of education cannot be effective (Croft et al, 2010),but other stakeholders of education had negative belief and less attention about teaching profession and teachers' professional development. They did not stand beside the school and teachers by providing the necessary professional, material, financial, and psychological support. Even, the stakeholders focused on political issues rather than academic issues in the school. This negatively influenced the participants and other stakeholder to develop new belief which was negative concerning their professional responsibility and practical work of ongoing teachers' professional development. That means, instead of working their 
professional development based on the previous positive beliefs they had about the program, the participants negatively approached the practical work of TPD and tried to do everything based on self-directed model of TPD just for the purpose of evaluation rather than the real purpose of the program. Concerning this, different scholars argue that without serious participation of internal and external stakeholders in teachers' professional development by providing the necessary support for the work, teachers cannot be successful in their professional development (Croft et al., 2010; Richards \& Farrell, 2005).This shows that external stakeholders' less attention towards TPD had played profound role forthe newly emerged teachers' belief which was negative about their profession and teachers' professional development andthe ineffectiveness of the participants' professional development of the school because teachers' teaching practices reflect their beliefs (Borg, 2003; Gilakjani \& Sabouri, 2017). To make positive belief and understanding of teachers sustainable, the role of stakeholders is critical because even if teachers have positive belief and understanding about TPD, they cannot be effective in their professional development unless they get serious attention and necessary support from other stakeholders of education.

As discussed above, the participants' professional development was not effective because it was based on selfdirected model of teachers' professional development. The teachers did not participate in needs assessment for topic selection of their professional development. As a result, the researcher observed the sampled EFL teachers when they simply took topics from their school leaders for their professional development which was not related with their needs and tried to separately work their professional development based on the given topics which is transmission approach of teachers' professional development. Consequently, the teachers tried to work their professional development just for the purpose of evaluation rather than for the real purpose of the program which is improving teaching practices and students' language proficiency. However, different literature informs us that when needs assessment and topic selection for teachers' professional development is accomplished by school leaders and teachers together, TPD of the school becomes effective because this way of professional development considers needs of the teachers, school and the teachers' wider role in achieving the educational objectives of the school system and country (Richards and Farrell, 2005; Hayes, 2014). Thus, effective teachers' professional development is one that allows teachers start from the existing needs rather than depending on things that are externally given for them.

Even, the teachers did not criticize the process of topic selection in the context of their professional development because they wrongly understood that the process of topic selection which is done only by the school leaders helps teachers collaboratively work their professional development. This shows that the teachers' professional development was profoundly based on transmission approach of TPD because their misunderstanding enforced the teachers consumed knowledge of others which is unrelated to their needs and actual work context (Borg, 2015), and the participants did not have awareness about practical ways of contemporary approach of teachers' professional development. Unless teachers are regularly given training on a reform like TPD, they simply accept what external experts give them concerning their professional development instead of looking it critically which is wrong.

Data from interviews, observations, and diary writings of the participants revealed that despite Ethiopian Education Policy and CPD framework advocating school-based models of TPD, the sampled teachers remained traditional involving individualistic approach of TPD. The teachers separately worked their professional development based on reading different published materials that are related with their field, listening English language radio programs, and taking few trainings in relation to English language teaching. When they were not clear with some points during their professional activities in the context of their professional development, they informally asked their colleagues and tried to get the point because there was no formally organized job-embedded collaborative TPD in the school. Although the strategy the teachers used in their professional development was not wrong by itself, it ought to be used as supplementary because the real and most important method of practicing one's professional development is based on job-embedded collaborative TPD. To do this, meaningful interactions among all stakeholders are needed (Villegas-Reimers, 2003; Croft, A. et al., 2010; Mora, Trejo, \& Roux, (2014). However, it is school leaders who are responsible to create conducive condition in which teachers work their professional development based on job-embedded TPD.

As we have seen above, the participants' professional development was based on self-directed model of teachers' professional development. The main reason for this was that including the school leaders, there was no stakeholder of education who made continuous follow-up and support for the teachers' professional development. However, one of the roles of school leaders in teachers' professional development is continuously creating conducive environment in which teachers collaboratively work their professional development based on school-based teachers' professional development. One of the ways that education leaders accomplish this is that by encouraging teachers actively participate in needs assessment and topic selection for their professional development and decision making of any professional activity because teachers' professional development should be relevant to individual teachers' needs, the school needs in which the teachers work, and the teachers' wider role in achieving the educational objectives of the school system and country (Alshumaimeri \& Almohaisen, 2017; Richards and Farrell, 2005).Schools and educators are expected to continuously and collaboratively evaluate their needs, cultural beliefs and practices in order to decide which professional development model would be most beneficial to their particular situation. However, even the teachers did not understand the way of topic selection for one's professional development because the school leaders did not try to train the teachers and create understanding about the process of needs assessment and topic selection for TPD which is participatory in which teachers work their professional development based on the existing needs.

When practically observed during out of classroom observation, the school leaders did not play the role of creating meaningful interactions among the community of the school as well as external stakeholders of education for the purpose of teachers' professional development of the school. They merely devised the program and gave it to the teachers, but there was nothing that they did beyond this for the effectiveness of the program in the school. For this reason, EFL 
teachers' professional development of the school was not effective because the teachers separately worked their professional development in the school. Being different from the school leaders' practical work regarding teachers' professional development, Richards \& Farrell (2005) and Jensen (2015) argue that effective school leaders' focus is on school based professional development. Using the strategy for teachers' professional development promotes discussions among teachers on their daily professional activities and feedbacks which help the teachers regularly learn from one another and strengthen the teachers' professional learning mindset to continuously improve their teaching practices and solve significant problems that the teachers and the school face in the teaching profession.

As one can see from the above descriptions, the sampled teachers also did not care about the physical condition of the school. The main reason for this was that the less attention the school leaders had about it. This shows that attention of both school leaders and teachers towards contemporary approach of TPD which has solution for every professional problem was weak because their attention regarding the negative impact that the unpleasant physical condition of the teaching classrooms have on instructional processes and towards correcting the problems as much as possible (Richards \& Rodgers, 2001)was weak because there was lack of encouraging condition which enables them to do that.

During out of classroom observation, the researcher observed that there was lack of enthusiasm of the school leaders about creation of favorable condition for effective teachers' professional development. In the condition, the researcher observed that due to weighty workload they had in the school, the participants could not freely and collaboratively work their professional development in the school. In the condition, the researcher did not observe when the school leaders made effort to solve the problem by creating conducive condition in which the teachers freely and collaboratively work their professional development. As a result, the teachers could not formally meet and collaboratively work their professional development in the school. In contrast of this, Ministry of Education (2009) and Villegas-Reimers (2003) give direction that it is the responsibility of school leaders that create conducive condition in which teachers freely and collaboratively work their professional development. School leaders' willingness is critical to create favorable situation which enables teachers freely and joyfully work their professional development.

The school leaders neither produced materials for TPD nor coordinated other stakeholders to contribute the necessary materials for the purpose of teachers' professional development. They did not make effort to create favorable condition independently by using human resource they had at their hand and producing professional learning materials. In addition, they did not coordinate other stakeholders' participation to contribute their treasure for this purpose because reluctant school leaders cannot do what they should do and motivate teachers to improve their teaching practices starting from within (Jensen, 2015). As a result, EFL teachers were observed when they tried to be reluctant about their professional responsibility they have regarding TPD because they developed negative belief regarding TPD. If school leaders create conducive condition by facilitating all stakeholders of education concerning TPD of their school, teachers' professional development becomes effective.

Because of lack of attention at the side of stakeholders of education for teachers' professional development of the school, the sampled teachers' professional development was based on traditional model of TPD. This negatively impacted the teachers' teaching practices. As the researcher understood from the teachers' diary writings and classroom observations, although the sampled EFL teachers of the target school language skills were good, their teaching method was profoundly based on transmission method. Instead of facilitating and enabling students collaboratively learn and construct their own knowledge based on the given lessons (Bada, 2015; Cey, 2001), the teachers simply dominated everything in the teaching classrooms. They, for instance, did not organize students in pair or group for the purpose of collaborative learning. Instead of doing this, they considered themselves as owners of knowledge and dominated everything in the classrooms and considered students as objects who passively receive knowledge from their teachers only that is transmission approach of schooling (Eba, 2013; Bada, 2015; Kumaravadivelu, 2006, Johnson, 2004). In addition, instead of using different teaching aids which make lessons link with the real life of students (Arahk; 2011), the teachers only used students' textbook in classroom teachings. For this reason, the students were enforced to learn the lessons without linking theory with practice. This implies that there was no sustainable supportive condition in which the teachers could develop their profession based on the current approach of TPD which enables them use contemporary approach of teaching in their classrooms.

Moreover, the teachers did not try to create suitable and attractive classroom environment for the instructional process they responsibly led in the classrooms. On top of disorganized seats of students in the classrooms, the physical condition of the classrooms - the roofs, walls, floors, windows, doors, seats, and blackboards of the classrooms - were profoundly deteriorated. For this reason, it was very unpleasant to be in the classrooms for the purpose of teachinglearning process. When these all were worsened, the teachers were not observed when they tried to amend the worsened classrooms as much as possible to make them attractive because they were negatively influenced by the less attention of the school leaders about it. In relation to this, there is evidence that since attractive condition has positive impact on instructional process, school leaders and teachers are responsible to keep every condition of teaching-learning process attractive (Day \& Sammons, 2016; Richards \& Rodgers, 2001) that is understood when ongoing and effective TPD is in the school.

So, to have positive beliefs about the practical work of TPD and be effective in their professional development practices, teachers need to be supported and inspired towards contemporary approach of TPD - collaborative TPD that enables them achieve their potential (Hayes, 2014; Borg, 2015). In doing so, the teachers' professional development addresses practical problems that the teachers face in their career (Jensen, 2015). However, the sampled teachers of the school did not get such opportunity. As a result, they developed negative beliefs regarding TPD and used self-directed model of TPD which negatively impacted the teachers teaching process. 


\section{Conclusion and Recommendations}

The participants of the research had good beginning in their positive beliefs about teachers' professional development. However, they had lack of sustainable support from other stakeholders of education to put their beliefs into practice andhave up-to-date knowledge, skills, and positive beliefregarding their profession and practical work of teachers' professional development. This negatively impacted the participants to develop negative belief about the teaching profession and practical work of TPD and use top-down approach of TPD in the context of their PD. This implies that if there were stakeholders of education who devotedly and regularly facilitate and train the teachers concerning teachers' professional development and make regular follow-up and the necessary supportregarding the progress of the participants' professional development, the teachers would not develop negative belief about the practical work of their professional development and use traditional approach of teachers' professional development. However, they did not get such stakeholders in the context of their professional development.

So, because of the discouraging condition, the teachers developed negative beliefs about the practical work of their professional development. There was no created favorable condition for the work of teachers' professional development in the school because external stakeholders who have authority and responsibility to accountably facilitate everything for the work had not positive belief about the teachers as well as teachers' professional development in the school. They did not collaboratively work for the effectiveness of TPD of the school. Consequently, the teachers developed negative belief about the practical work of teachers' professional development, and their PD practices became traditional. Even, their work of professional development that was based on traditional approach of TPD was for the purpose of evaluation rather than real purpose of TPD which is improving teachers' teaching practices that in turn improves students' language learning performance. This shows that if a teacher is motivated to effectively accomplish different works in a school, he or she develops positive belief about the works and becomes effective in his or her career. This displays that the teacher cannot be effective to achieve the work well unless he or she is motivated and has positive beliefs about the work. The same is true for his or her teaching profession and professional development.

Therefore, to make EFL teachers effective in their career, external and internal stakeholders are expected to have positive beliefs and be supportive concerning the teaching profession in general and teachers' professional development in particular. Similarly, the teachers are expected to have commitment which enables them practically put their belief that they have about TPD into practice based on the contemporary approach of teaching-learning theory and ethics of the profession.

\section{References}

i. Abad, V. J. (2012). Pedagogical Factors that influence EFL Teaching. Some considerations for teachers' professional development profile. Bogota, Colombia, 15(1), 97-108.

ii. Abdi, H., \&Asadi, B. (2015).A synopsis of researches on teachers' and students' beliefs about language learning.International Journal on studies in English Language and Literature (IJSELL), 3(4), 104-114.

iii. Alfaki, I. M. (2014). Professional development in English language teaching: A teacher's view. British Journal of Education,2(7), 32-49.

iv. Alshumaimeri, A.Y., and Almohaisen M. F. (2017). Saudi EFL teachers' perceptions of professional development activities. Journal of education \& social policy, 7(1), 1-9.

v. Arahk, K. E. (2011). The use of authentic materials in the second language classrooms: advantages and disadvantages. DilDergisi. Sayl.

vi. Asmari, A. R. A. (2016). Continuous professional development of English language teachers: Perception and Practices. Australian International Academic Center, Australia journal, 7(3), 117-124.

vii. Bada, S.O. (2015). Constructivism learning theory: A paradigm for teaching and learning. Journal of research and method in education, 5, 66-70.

viii. Bolitho, R., and Padwad, A. (2013).Continuous professional development: Lessons from India. British Council.

ix. Borg, S. (2003). Teacher cognition in language teaching: A review of research on what language teachers think, know, believe, and do. Language teaching, 36(2), 81-109.

x. Borg, S. (2015). Professional development for English language teachers: Perspectives from higher education in Turkey. British Council: Teaching English, ISBN 978-0-86355-764-4.

xi. Cey, T. (2001). Moving towards constructivist classrooms. University of Saskatchewan Saskatoon, Saskatchewan.

xii. Croft, A. et al. (2010).Job-embedded professional development: What it is, who is responsible, and how to get it done well.National comprehensive center for teacher quality, Mid Atlantic, national staff development council.

xiii. Davidson, G., Dunlop, F., Soriano, H. D., Kennedy, L., \& Philips, T. (2012). Continuing professional development for English language teachers in the UK: British Council.

xiv. Day, C. and Sammons, P. (2016). Successful school leadership: Education development trust: The University of Nottingham: United Kingdom, High bridge House, Malaysia: University of Oxford.

xv. Diaz-Maggioli, G. (2004). Teacher-centered professional development: Association for supervision and curriculum development, Alexandria, Virginia USA.

xvi. Eba, M. (2013). The need for professional growth of ELT teachers in Ethiopia.Star journal, 2(3), 160-168.

xvii. Gilakjani, P. A., and Sabouri, B. N. (2017). Teachers' beliefs in English language teaching and learning: A review of the literature: Published by Canadian center of science and education: English language teaching; 10(4).

xviii. Gulamhussein, A. (2013). Teaching the teachers. Effective professional development in an era of high stakes accountability. National School Boards Association: Center for Public Education. 
xix. Hayes, D. (2014). Innovations in the continuing professional development of English language teachers. British Council: Teaching English. London, SW1A 2BN, UK.

xx. Jensen, B. (2015). Building leader and educator capacity for transformation: Transformation framework. Microsoft Corporation.

xxi. Johnson, M. (2004). A philosophy of second language acquisition. Yale University Press, New Haven \& London

xxii. Kocaman, O. and Cansiz, G. (2012). Teachers' beliefs about teaching English to elementary school children: International conference on horizons in education Inte2012: Procedia-Social and Behavioral Sciences 55, 2012, 799-808.

xxiii. Korkmazgil, S. (2015).An investigation into Turkish English language teachers perceived professional development needs practices and challenges. Middle East University.

xxiv. Kumaravadivelu, B. (2006). Understanding language teaching:From method to post method. San Jose State University, Lawrence Erlbaum associates PUBLISES Mahwah, New Jersey, London.

xxv. Kuzborska, I. (2011). Links between teachers' beliefs and practices and research on reading. Reading in a foreign language, 23(1), 102-128.

xxvi. Ministry of Education (2009).Continuous professional development for primary and secondary school teachers, leaders and supervisors in Ethiopia: The framework.Federal democratic republic of Ethiopia. Addis Ababa.

xxvii. Mora, A., Trejo, P., \& Roux, R. (2014). English language teachers' professional development and identities:PROFILE Issues in Teachers' Professional Development. International journal of research in social sciences, $16(1), 49-62$.

xxviii. Oxford Dictionary (1999).Oxford advanced learners' dictionary.Oxford University press.

xxix. Richards, C. J., and Farrell, C. S. T. (2005). Professional development for language teachers: Strategies for teacher learning. Cambridge University Press: New York, NY 10011-4211, USA.

xxx. Richards, C. J., and Lockhart, C. (1996). Reflective teaching in second language classrooms. Cambridge University Press. New York.

xxxi. Richards, C. J., and Rodgers, S. T. (2001).Approaches and methods in language teaching (2 ${ }^{\text {nd }}$ edition).Cambridge University press.

xxxii. Solak, E. (2016). Professional development in ELT.Amasya University: Published by NuansKitapcilik San.Ve Tic. Ltd.Sti.

xxxiii. Villegas-Riemers (2003).Teacher professional development: An international review of the literature. UNESCO: international institute for educational planning.

xxxiv. Xu, L. (2012). The role of teachers' beliefs in the language teaching-learning process. Academy Publisher Manufactured in Finland: Theory and Practice in Language Studies, 2(7), 1397-1402. 